\title{
Pseudomonas syringae Responds to the Environment on Leaves by Cell Size Reduction
}

\author{
J.-M. Monier and S. E. Lindow
}

Department of Plant and Microbial Biology, University of California, Berkeley 94720. Accepted for publication 17 April 2003.

\begin{abstract}
Monier, J.-M., and Lindow, S. E. 2003. Pseudomonas syringae responds to the environment on leaves by cell size reduction. Phytopathology 93:1209-1216.

The length and volume of cells of the plant-pathogenic bacterium Pseudomonas syringae strain B728a were measured in vitro and with time after inoculation on bean leaf surfaces to assess both the effect of nutrient availability on the cell size of $P$. syringae and, by inference, the variability in nutrient availability in the leaf surface habitat. Cells of $P$. syringae harboring a green fluorescent protein marker gene were visualized by epifluorescence microscopy after recovery from leaves or culture and their size was estimated by analysis of captured digital images. The average cell length of bacteria grown on leaves was significantly smaller than that of cultured cells, and approached that of cells starved in phosphate buffer for $24 \mathrm{~h}$. The average length of cells originally grown on King's medium $B$ decreased from $\approx 2.5$ to $\approx 1.2 \mu \mathrm{m}$ by 7 days after inocu-
\end{abstract}

ABSTRACT

The leaf surface environment is considered to be a stressful habitat for bacterial populations due to the limitations of nutrients and water availability, changes in temperature, and exposure to UV and visible irradiation. Even if environmental conditions on the leaf surface are not extreme per se, epiphytic bacteria have to cope with constantly changing conditions during the course of the day and through leaf development. Despite this, a large diversity of saprophytic and plant-pathogenic bacterial species are able to grow and maintain large population sizes on leaf surfaces under these harsh environmental conditions $(6,7)$.

The availability of nutrients on leaves seems to have an important effect on the size and composition of epiphytic populations $(29,33,52)$. Although an extensive list of organic and inorganic compounds have been identified in leachates of leaves $(14,43)$, it has been shown that the epiphytic population sizes are limited by the availability of carbon-containing compounds $(29,51)$. Several studies have demonstrated that epiphytic population sizes can be increased by addition of carbon, but not by applying nitrogen or phosphate alone to the leaf surface $(33,51,53)$.

Bacteria can adapt to nutrient limitation by a variety of mechanisms (21,31). Under conditions of limited exogenous nutrients, bacterial cells undergo a number of morphological and physiological changes $(9,34,36,41)$. Most apparent are alterations in the macromolecular constituents of the bacterial cell $(3,12,15)$ and in cell shape $(13,20,23)$. Baker et al. (3) reported that nutrient-deprived cells of Vibrio cholerae become coccoid and lost over $90 \%$ of their original volume within 30 days. The surviving cells, although smaller, developed increased resistance to acid, oxidative

Corresponding author: S. E. Lindow; E-mail address: icelab@socrates.berkeley.edu.

Publication no. P-2003-0728-02R

(c) 2003 The American Phytopathological Society lation on plants. Some decrease in cell size occurred during growth of cells on leaves and continued for up to 13 days after cell multiplication ceased. Although cultured cells exhibited a normal size distribution, the size of cells recovered from bean plants at various times after inoculation was strongly right-hand skewed and was described by a log-normal distribution. The skewness of the size distribution tended to increase with time after inoculation. The reduced cell size of $P$. syringae B728a on plants was readily reversible when recovered cells were grown in culture. Direct in situ measurements of cell sizes on leaves confirmed that most cells of $P$. syringae respond to the leaf environment by reducing their size. The spatial heterogeneity of cell sizes observed on leaves suggest that nutrient availability is quite variable on the leaf surface environment.

Additional keywords: epiphyte, foliar pathogen, phyllosphere, propidium iodide.

stress, and lytic enzymes $(10,47)$. Prolonged incubation of Pseudomonas fluorescens in bulk soil or under carbon-deprived conditions in vitro resulted in a decrease in cell length and an increase in resistance to abiotic stress $(17,42,46)$. Similar results were observed with P. putida (12) and Rhizobium spp. (35). In all cases, addition of glucose to the habitat counteracted cell shrinkage. Similar studies have demonstrated that bacterial cells in soil respond to nutrient addition by cell enlargement $(2,4)$. Although other environmental factors such as temperature (48) and osmolarity of the growth medium $(5,22)$ have been reported to affect the size of bacteria, cell size reduction appears to be induced predominantly by nutrient limitation, and there is a consistent trend for the bacteria in oligotrophic environments to be smaller than the bacteria in eutrophic environments $(10,11,30,44,45)$. Clearly, changes in cell size reflect changes in the environment to which cells have been exposed, and conversely, study of cell size can provide information on the nature of microbial habitats and can be used as an indicator of the trophic status of the bacteria (30).

$P$. syringae is a plant-pathogenic bacterium commonly found on leaf surfaces. It can cause disease on many plant species, and due to its ice-nucleation activity, it can incite frost damage. This species often establishes large epiphytic populations on host and nonhost plants (19). Studies have shown that the establishment of large epiphytic populations is a prerequisite for disease occurrence (37) and that population sizes of $P$. syringae on leaves of a host plant such as bean are predictive of the incidence of subsequent disease $(18,25)$. The majority of the cells of $P$. syringae are present on the plant surface (49) and occur in a variety of states of aggregation (J.-M. Monier and S. E. Lindow, unpublished data). In preliminary studies, we observed that $P$. syringae cells on leaves often are much smaller than those in culture and also more heterogeneous in size. Our observations indicate that the size of $P$. syringae cells are associated with their location on the leaf; cells near potential sites of nutrients such as glandular trichomes or 
veins seemed larger than cells further from these sites. These observations suggest that cells of $P$. syringae are able to respond to their local environmental conditions on the leaf surface by altering their size.

To our knowledge, few studies have described changes in cell size of plant-associated bacteria. A study conducted with $P$. syringae pv. tabaci cultured in vitro and infiltrated into tobacco leaves concluded that changes in bacterial size in planta were related to the growth phase of the population and is therefore determined primarily by endogenous factors rather than leaf environment (39). Bjorklof et al. (8) observed that $P$. syringae cells become shorter during incubation on bean leaf. While these studies indicate that cell size in $P$. syringae is potentially dynamic in natural habitats, they were insufficiently detailed to provide information on the temporal dependence of such cell size changes or on the variations of populations of cells in a potentially heterogeneous leaf environment.

The objective of our study was to quantify the temporal effect of leaf surface colonization on bacterial cell size and to obtain insight into how variable the leaf surface environment is by determining the heterogeneity of bacterial cell size on plants. In order to conduct experiments under realistic conditions on plants harboring a diverse bacterial flora, we monitored cell size of a strain of $P$. syringae that was genetically marked with a $g f p$ gene conferring green fluorescence. We demonstrate important phenotypic differences between cells grown in vitro and on leaves and discuss the implications for the epidemiology of bacterial disease and for strategies of control of epiphytic plant-pathogenic bacteria.

\section{MATERIALS AND METHODS}

Bacterial strains and culture media. $P$. syringae pv. syringae B728a is a spontaneous rifampicin-resistant derivative of a strain isolated from a bean leaflet. Its characteristics have been previously reported $(19,27)$. Cultures were stored at $-80^{\circ} \mathrm{C}$ in $15 \%$ glycerol (vol/vol) in $10 \mathrm{mM}$ potassium phosphate buffer (PB), $\mathrm{pH}$ 7.0, and routinely grown on King's medium B (KB). Plasmid DNA was isolated from Escherichia coli DH5 $\alpha$ (pKT-trp) (16) with a DNA isolation kit (Qiagen Inc., Valencia, CA) and was transferred into $P$. syringae $\mathrm{B} 728$ a by electroporation according to standard procedures (38). The plasmid pKT-trp consists of a $g f p$ marker gene driven by the trp promoter from Salmonella typhimurium (16) that yields constitutive expression in $P$. syringae.

Plant inoculation and estimation of bacterial population sizes. All experiments were conducted with 2-week-old bean plants (Phaseolus vulgaris cv. Bush Blue Lake 274) grown in a greenhouse and incubated under controlled conditions in the laboratory. The bacteria were applied by immersing the plants in a suspension of $P$. syringae $\mathrm{B} 728 \mathrm{a}$ (pKT-trp) $\left(10^{5} \mathrm{CFU} / \mathrm{ml}\right.$ in $\left.\mathrm{PB}\right)$ for about $3 \mathrm{~s}$. The plant pots were covered with a plastic bag, sealed loosely at the base of the pot to provide conditions of $100 \%$ relative humidity $(\mathrm{RH})$, and incubated at $22^{\circ} \mathrm{C}$ in the laboratory. Bacterial populations were estimated from 10 individual symptomless leaves randomly sampled from each plant pot. Each leaf was placed in $20 \mathrm{ml}$ of washing buffer $(100 \mathrm{mM} \mathrm{PB}, \mathrm{pH} 7.0$, containing $0.1 \%$ Bacto-peptone [Difco Laboratories, Detroit]) and sonicated for $7 \mathrm{~min}$ in an ultrasonic cleaning bath to recover bacterial cells. Appropriate dilutions of leaf washings were plated on $\mathrm{KB}$ containing rifampicin $(100 \mu \mathrm{g} / \mathrm{ml})$, cycloheximide $(100 \mu \mathrm{g} / \mathrm{ml})$, and benomyl $(50 \mu \mathrm{g} / \mathrm{ml})$ (Sigma Co., St. Louis) with a spiral plater (Spiral Systems Inc., Cincinnati). The population sizes were estimated from plate counts made after 2 to 3 days incubation at $28^{\circ} \mathrm{C}$.

Microscopy of bacteria cultured in vitro. The dimensions of cells grown on solidified $\mathrm{KB}$ (KBA), KB broth (KBB), or cells starved in $\mathrm{PB}$ were compared. Cells grown on KBA for $24 \mathrm{~h}$ at $28^{\circ} \mathrm{C}$ or in $\mathrm{KBB}$ to mid-exponential phase (optical density at $600 \mathrm{~nm}=0.7)$ were resuspended in $\mathrm{PB}$, centrifuged $(10 \mathrm{~min}$ at $5,000 \times g$ ), and resuspended in water, and the concentration was adjusted to $10^{7} \mathrm{CFU} / \mathrm{ml}$. Each experiment was done in triplicate. In one experiment, cells grown on KBA were also resuspended in $\mathrm{PB}$ to a concentration of $10^{7} \mathrm{CFU} / \mathrm{ml}$ and the cells were starved at room temperature for $24 \mathrm{~h}$. In order to identify dead cells in our measurements, each suspension was stained with propidium iodide $(10 \mu \mathrm{g} / \mathrm{ml})$ for $10 \mathrm{~min}$ in the dark at room temperature. Five microliters of each suspension was mixed with $5 \mu \mathrm{l}$ of Polymount, a non-fluorescing mounting medium (Polysciences Inc., Warrington, PA), deposited on a slide, covered with a coverslip, and immediately observed under the microscope.

Microscopy of bacteria inoculated onto bean leaves. Dimensions of bacterial cells on bean leaves were measured both after recovery of the cells from leaves and directly on leaf surfaces. Plants were inoculated with suspensions $\left(10^{5} \mathrm{CFU} / \mathrm{ml}\right)$ of cells grown on KBA, KBB, or cells starved in $\mathrm{PB}$. The use of the green fluorescent protein (GFP) as a marker gene allowed us to visualize exclusively the inoculated cells of $P$. syringae strain B728a (pKTtrp) on bean plants. The use of such plants enabled us to assess the response of immigrant $P$. syringae cells to realistic environmental conditions. Each experiment was done in triplicate, and three to five individual leaves were randomly sampled at each sampling time. Bacteria recovered from leaf surfaces by sonication of symptomless leaves were stained with propidium iodide for 10 min in the dark at room temperature and filtered through black polycarbonate filters $(0.2-\mu \mathrm{m}$-diameter pore size) (Millipore Co., Bedford, MA). The filters were placed between a microscope slide and a coverslip with $10 \mu \mathrm{l}$ of Polymount and were immediately observed by epifluorescence microscopy. At least 20 random fields of view, containing a total of at least 400 cells, were observed per slide. In situ measurements were obtained from the upper leaf surfaces 2 and 6 days after inoculation of plants with a suspension of bacteria grown on KBA. Segments of approximately 1 by $1 \mathrm{~cm}$ were randomly cut from leaves and placed on top of $100 \mu$ of melted water agar $(1 \%)$ on a microscope slide in order to ensure a flat surface for microscopic observations. After solidification of the agar (in about $20 \mathrm{~s}$ ), $10 \mu \mathrm{l}$ of a solution of propidium iodide $(10 \mu \mathrm{g} / \mathrm{ml})$ in Polymount was placed on the center of a coverslip which was then gently pressed down onto the leaf segment. The mountings were kept in the dark at room temperature for $10 \mathrm{~min}$ and then observed by epifluorescence microscopy. Images corresponding to randomly selected fields of view were captured, the presence of anatomical leaf structures was noted, and all the cells present in the image were measured. Mounting of the samples with Polymount fixed the cells but did not decrease the quality of the images, giving us the ability to capture high-quality images and providing information about the spatial distribution of the cells without artifacts due to the relocation of the cells which often happen with a water-based mounting medium. Furthermore, our method of observation allowed us to visualize the different leaf structures (stomates, trichomes, and veins) which provided information about the spatial location of the cells of $P$. syringae on the leaf surface.

Image acquisition and measurements of cell size. All samples were observed with an Axiophot Zeiss microscope equipped with a $\times 100 / 1.30$-numerical-aperture Plan Neofluar oil immersion objective (Zeiss Inc., Oberkochen, Germany). Phase contrast microscopy was used to compare cell sizes of the wild type and $g f p$ marked strains. All other mountings were examined by epifluorescence microscopy with a filter set for fluorescein to detect GFP in combination with a short pass filter $(650 \mathrm{~nm})$ to partially block the red autofluorescence of the leaf but not the propidium iodide signal. Images were captured with a video camera (Model DEI750; Optronics, Goleta, CA) and visualized on a Macintosh platform. In order to represent measurements in micrometers, the microscope and video camera were calibrated using a micrograded slide with parallel stripes separated by known distances. Final images captured were 640 by 480 pixels with a resolution of $0.081 \mu \mathrm{m}$ pixel $^{-1}$. Images were transferred to a PC platform and first processed 
with Corel Photopaint software (Corel Co., Ottawa, Canada). Bacterial cells completely or partially out of focus were deleted from the images. Bacteria stained with propidium iodide were also deleted. Images were then manually thresholded to separate bacteria from the background and converted into binary images before conducting cell size measurements using IPLab software (Scanalytics Inc., Fairfax, VA), which allowed automatic measurements of the length and diameter of each individual bacterium. Between 300 and 900 individual cells from at least 15 different images were measured for each replicate obtained by leaf washing or in vitro cultures and at least 100 individual cells per replicate for direct images of leaf surfaces.

Estimation of bacterial cell volume. Epifluorescence microscopy combined with image analysis allowed us to measure the projected area of an object. The number of pixels that defined the object was used to determine the major axis, $L$ (cell length), and the minor axis, $d$ (cell diameter). Based on the observation that $P$. syringae cells are rod-shaped bacteria (cylinders with hemispheric ends), we estimated the volume, $V$, of an individual cell by

$$
V_{\text {cell }}=\frac{\pi d^{2}}{4}\left(L-\frac{d}{3}\right)
$$

Data transformation and statistical analysis. Conversion of pixels into micrometers and estimation of cell volumes were done using Microsoft Excel software. Descriptive statistics and tests for normality (Kolmogorov-Smirnov; MaxD, $P$ ) were performed with the software Statistica (Statsoft Inc., Tulsa, OK). Because all samples of cells recovered from plants exhibited a log-normal distribution, the length and diameter of each individual cell were logarithmically transformed prior to statistical analyses as follows: $x^{\prime}=\log (x+1)$. Duncan's multiple range test was used to compare means in a given experiment and was performed using SAS (SAS Institute, Cary, NC).

\section{RESULTS}

Impact of GFP on cell size and epiphytic fitness. To differentiate $P$. syringae cells from indigenous bacteria on the leaf surface, plants were inoculated with $P$. syringae strain B728a harboring a constitutively expressed $g f p$ marker gene on the stable plasmid pKT-trp. Wild-type strain B728a and its derivative B728a (pKT-trp) exhibited no significant differences in their growth rate on KBB (data not shown), in their growth rate or maximum population size on plants under conducive conditions (high $\mathrm{RH}$ ), and in their survival under stressful conditions (low RH) after inoculation of leaves (Fig. 1A). Also, after $24 \mathrm{~h}$ growth on KBA, the cell dimensions of these two strains measured by phase contrast microscopy did not differ (Fig. 1B). Thus, the expression of GFP did not appear to impact the wild-type behavior of B728a on plants or in culture. The average cell length of strain B728a (pKTtrp) measured by epifluorescence microscopy $(2.48 \pm 0.02 \mu \mathrm{m})$ was not significantly different from that measured by phase contrast microscopy $(2.53 \pm 0.03 \mu \mathrm{m})$.

Cell size after inoculation of leaves. Cell size reduction in $P$. syringae is an active process, because dead cells on slides remained intact and without significant changes in size for several days (data not shown). The use of propidium iodide as a stain for membrane compromised cells allowed us to disregard dead cells in our measurements which would have resulted in an overestimation of the size of living cells. Samples were observed with an epifluorescent microscope equipped with a fluorescein filter that enabled us to visualize both living cells (green) and dead cells (red) of $P$. syringae on the same image.

The size of cells of strain B728a (pKT-trp) was determined as a function of time after inoculation on leaf surface. The average cell size of B728a (pKT-trp) grown on KBA and used as inoculum was $\approx 2.6 \mu \mathrm{m}$ and progressively decreased with time after inoculation onto plants (Fig. 2A to D) and reached an average size of $\approx 1.2 \mu \mathrm{m}$ after 15 days (Fig. 3). By 2 days after inoculation, cell size had decreased by about $35 \%$ and a further decrease occurred up to 15 days. Because bacteria grow rapidly after inoculation onto plants and achieve high and stable populations within about $48 \mathrm{~h}$ after inoculation, we also examined in more detail the changes in cell size that occurred during this initial phase of plant coloniza-
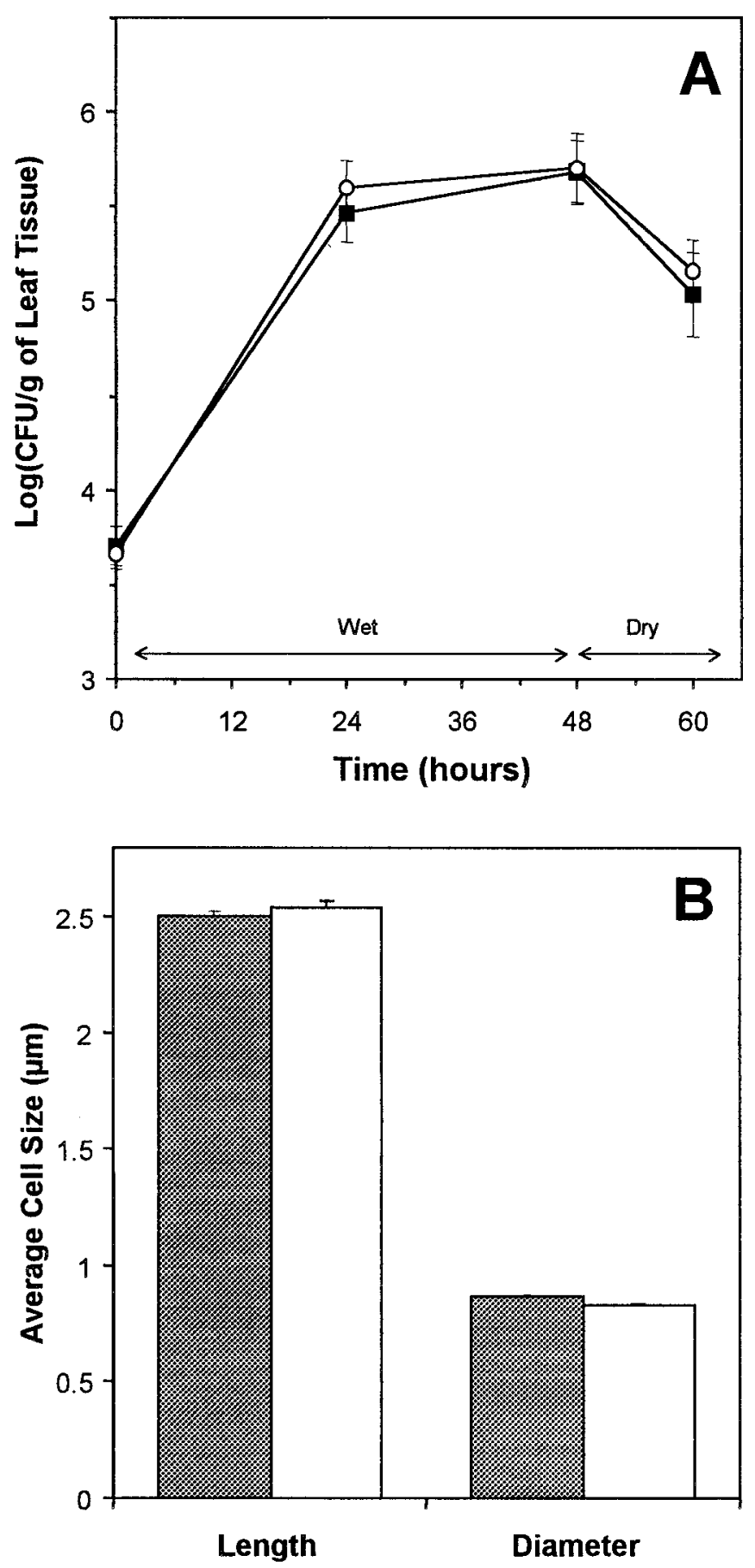

Fig. 1. Effect of the green fluorescent protein marker gene on Pseudomonas syringae $\mathrm{B} 728 \mathrm{a}$ population size and cell dimensions. A, Comparison of population sizes of wild-type strain B728a (-) and B728a (pKT-trp) (O) on bean leaf surfaces after inoculation under conducive (wet) conditions and after transferring the plants to stressful (dry) conditions. A total of 10 leaves were randomly sampled at each time point. B, Cell dimensions of strain B728a (gray column) and B728a (pKT-trp) (white column) grown on solidified King's medium B were not significantly different $(P=0.29)$. Data represent the average value of three independent experiments for which at least 400 cells were measured. Vertical bars represent the standard error of the mean. 
tion. Cell size reduction occurred rapidly upon inoculation onto plants, even as cell populations were increasing (Fig. 4), and continued to decrease, although at a slower rate, as cell multiplication ceased after $24 \mathrm{~h}$. No visible symptoms of disease were observed even after extended incubations at high $\mathrm{RH}$.
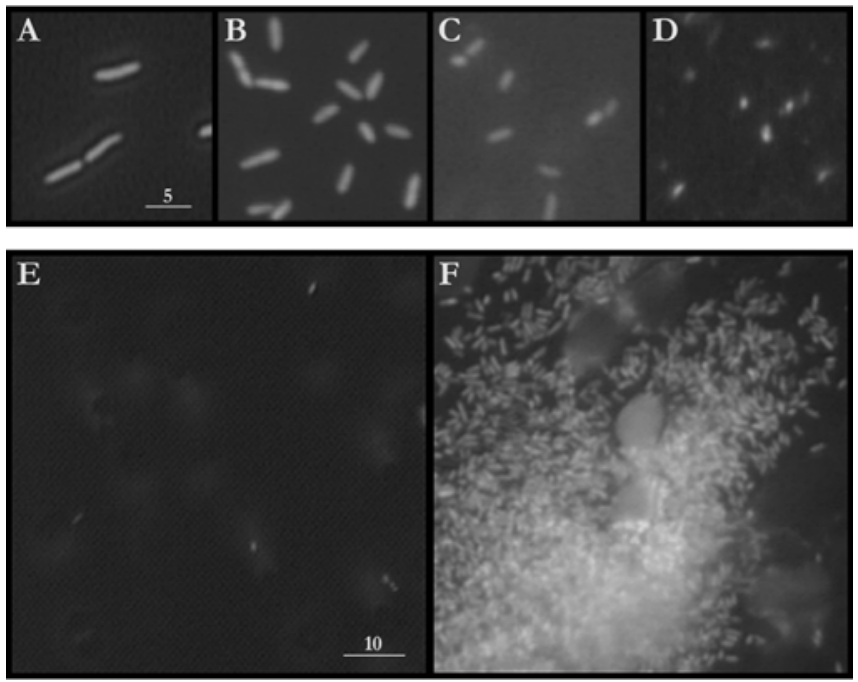

Fig. 2. Cells of Pseudomonas syringae strain B728a harboring a green fluorescent protein marker gene, observed by epifluorescence microscopy following growth on A, King's medium B (KB) broth or $\mathbf{B}$, solidified $\mathrm{KB}$ or $\mathbf{C}$, after recovery from leaf surfaces after 2 days and $\mathbf{D}, 15$ days incubation. Measurements performed 6 days after inoculation revealed that $\mathbf{F}$, aggregated cells, often found associated with glandular trichomes, were significantly longer than $\mathbf{E}$, solitary cells. Images were converted to grayscale. White bars represent $5 \mu \mathrm{m}$ (A to $\mathbf{D})$ and $10 \mu \mathrm{m}(\mathbf{E}$ and $\mathbf{F})$.

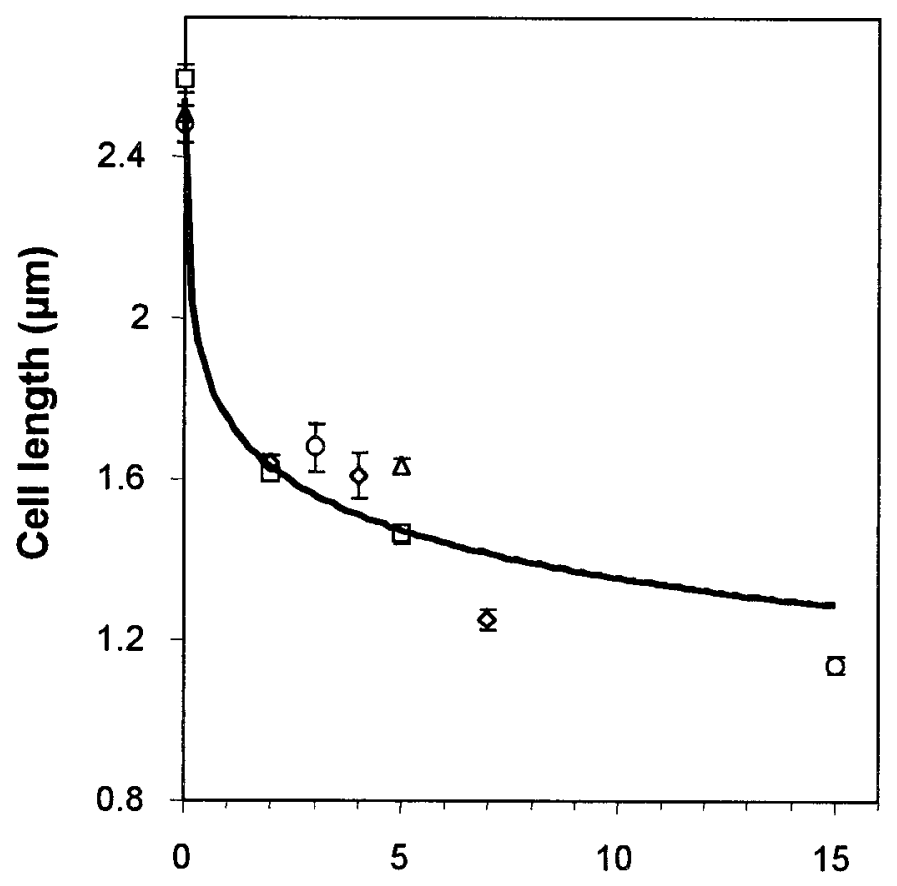

\section{Days since inoculation}

Fig. 3. Average length of solidified King's medium B-grown cells of Pseudomonas syringae $\mathrm{B} 728 \mathrm{a}$ (pKT-trp) at various times after inoculation onto bean leaf surfaces. Each symbol type represents an independent experiment. Plants were inoculated with a bacterial suspension and maintained under high relative humidity conditions until the time of sampling. Vertical bars represent the standard error of the mean cell length at a given sample time. The regression line $\left(y=-0.17 \operatorname{Ln}(x)+1.75, R^{2}=0.959\right)$ was arbitrary drawn to show the trend.
Inoculation of plants with bacteria of different cell size. To determine if the cell size of the bacterial inoculum influenced size after inoculation onto leaves, we treated plants with suspensions of bacteria grown on KBA, KBB, or starved in PB. For each suspension, a 100-fold increase in population sizes was observed after 2 days of incubation on leaves (data not shown). The average length of bacterial cells grown in $\mathrm{KBB}$ was $3.5 \mu \mathrm{m}$, almost $1 \mu \mathrm{m}$ greater than cells grown on KBA (Fig. 2A and B). More importantly, cells grown on either of these media decreased in size within $24 \mathrm{~h}$ after they were placed in PB to a length of only about $2 \mu \mathrm{m}$. The size of the cells in the inoculum did not influence their size after inoculation onto the leaf (Fig. 5). The length of cultured cells decreased significantly within 2 days and approached an average minimum size of approximately $1.7 \mu \mathrm{m}$ in all cases. In contrast, the length of cells starved in PB before inoculation onto plants did not decrease appreciably within 5 days. The estimated volume of the cells in the inoculum was 1.74 (KBB), 1.35 (KBA), and $1.25 \mu^{3}$ (PB), whereas after 5 days of growth on leaves, the average volume of the cells decreased to $0.49,0.46$, and $0.44 \mu \mathrm{m}^{3}$, respectively; thus, cells were not significantly different from one another $(P>0.05)$. Thus, within 5 days after inoculation onto plants, the length (and volume) of cells grown on KBB was reduced by 2.0-fold (and 3.6-fold), whereas the length of cells grown on KBA or starved in PB was reduced by 1.4 -fold (and 2.9-fold) and 1.2-fold (and 2.9-fold), respectively.

Cell size frequency distributions and in situ measurements. Insight into the processes involved in changes in cell size of $P$. syringae on leaves was obtained by an analysis of distribution of cell sizes of bacteria measured directly in situ and those recovered from leaves at various times after inoculation. The sizes of cells grown in KBA were described by a normal distribution (Fig. 6A). We observed similar distributions of cell sizes in KBB-grown cells and PB-starved cells (data not shown). In contrast, cells recovered from bean plants at various times after inoculation were more variable in size (ranging in length from 0.5 to $5.0 \mu \mathrm{m}$ ), and

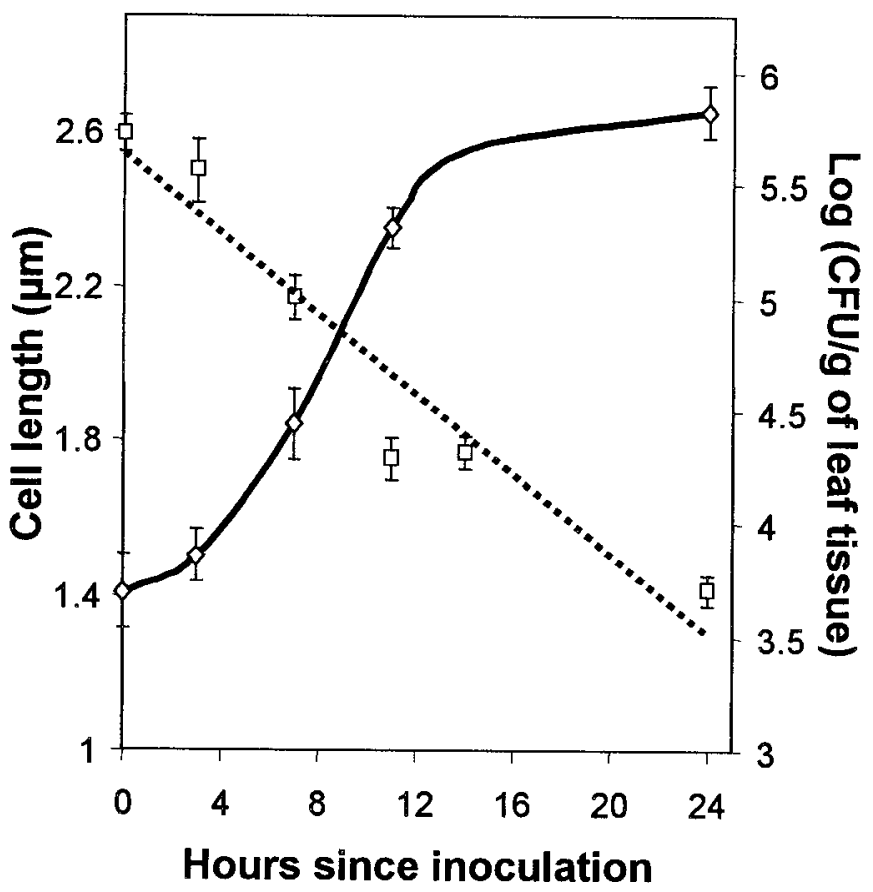

Fig. 4. Average length (squares) and corresponding population size (diamonds) of solidified King's medium B-grown cells of Pseudomonas syringae B728a (pKT-trp) during the first $24 \mathrm{~h}$ following inoculation of bean leaf surfaces. Vertical bars represent the standard error of the mean cell length and the mean population size at a given sampling time. Plants were inoculated with a bacterial suspension and maintained under high relative humidity conditions until the time of sampling. The dotted line $\left(y=-0.052 x+2.545, R^{2}=0.927\right)$ represents the regression of the cell length as a function of time. 
their size distribution was right-hand skewed and best described by a log-normal distribution (Fig. 6B to D). The skewness of the distribution tended to increase with time after inoculation, with the proportion of cells of small size increasing even though some large, live cells could still be recovered from plants (Fig. 6B to D).

The reduced cell size of $P$. syringae B728a (pKT-trp) on plants was reversible when the cells recovered from leaves were grown in culture. Bacteria recovered from leaves 7 days after inoculation had an average length (and volume) of $1.25 \mu \mathrm{m}$ (and $0.29 \mu \mathrm{m}^{3}$ ). After $48 \mathrm{~h}$ of growth of recovered cells on KBA, the average length and volume of the cells increased to $2.36 \mu \mathrm{m}$ (and $1.29 \mu \mathrm{m}^{3}$ ) (Fig. $6 \mathrm{E})$. The distribution of cell length reverted from a strong righthand skewed distribution to that of a normal distribution, with a mean size similar to that of the original inoculum, upon reculturing the cells (Fig. 6).

Direct in situ measurements were performed to determine if the size of cells on the plant was associated with particular anatomical features such as stomates, trichomes, and veins. Observations of cells of $P$. syringae B728a (pKT-trp) revealed that the relatively few large cells in the population were not dispersed randomly across the leaf surface but were instead localized in particular sites. In situ measurements made 6 days after inoculation revealed that the highest density of cells and the largest cells were almost exclusively located near glandular trichomes. Cells at these sites were significantly longer $(2.63 \pm 0.15 \mu \mathrm{m})$ than cells further away from these sites (e.g., three epidermal plant cells) (1.84 \pm $0.04 \mu \mathrm{m})(P<0.001)$ and were not significantly different in size from cells grown on KBA (Fig. 2) $(P=0.935)$. The size of cells of $P$. syringae B728a (pKT-trp) in situ $(2.07 \pm 0.09 \mu \mathrm{m})$ did not differ from that of cells washed from plants $(2.27 \pm 0.02)(P=0.096)$, indicating that the red autofluorescence of the leaves or the recovery process did not affect estimates of bacterial cell size on leaves. We conclude that the leaf surface environment is heterogeneous and that only a few immigrant cells subsequently experienced

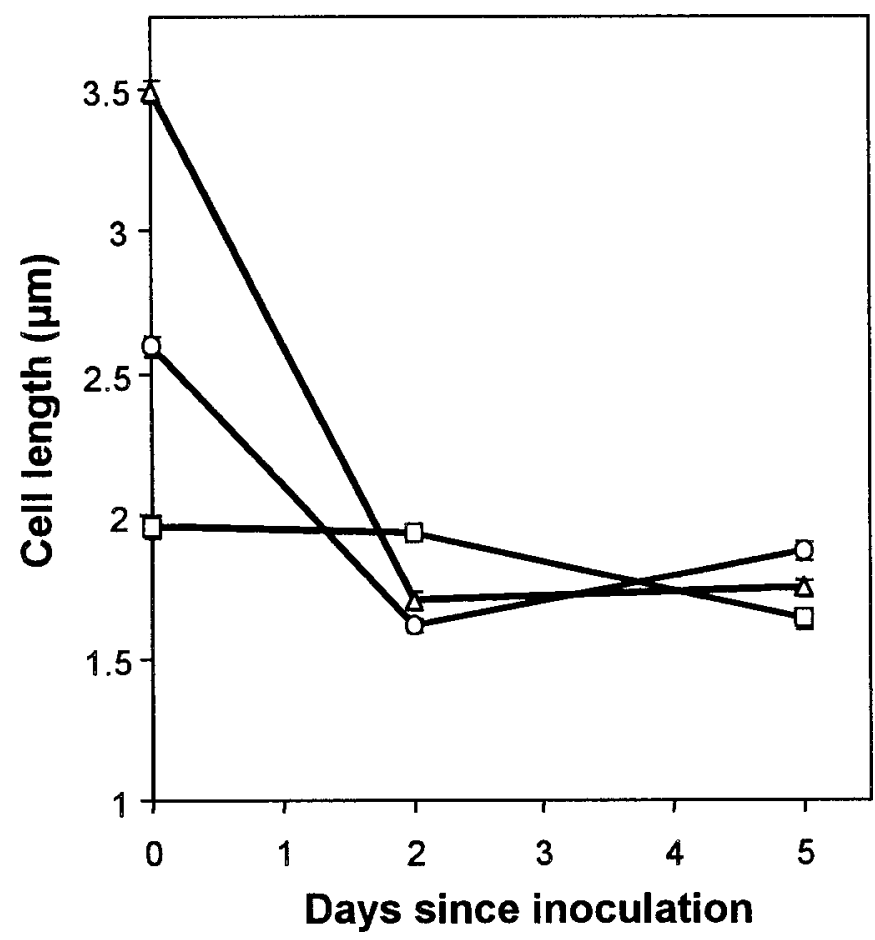

Fig. 5. Effect of inoculum cell size of Pseudomonas syringae B728a (pKTtrp) on the average length of cells recovered from leaf surfaces at various times after inoculation. $P$. syringae cells were grown on solidified King's medium B (KB) (circles) or KB broth (triangles) or starved for $24 \mathrm{~h}$ in potassium phosphate buffer (squares) prior to inoculation onto leaf surfaces. Vertical bars represent the standard error of the mean cell length at a given sample time.
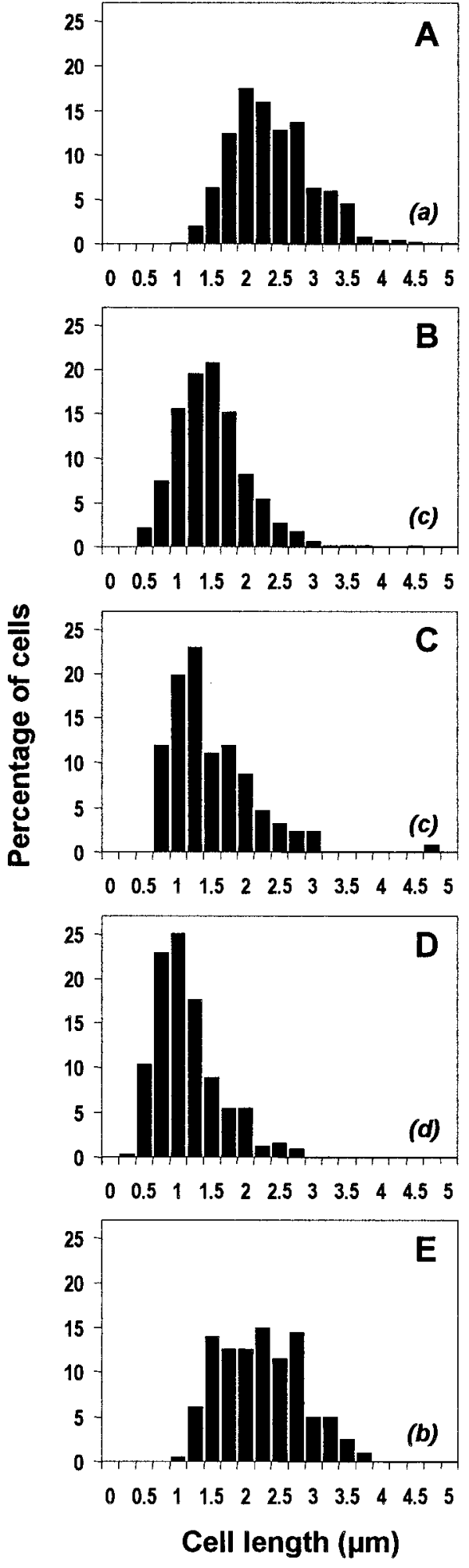

Fig. 6. Frequency distribution of bacterial cell lengths on $\mathbf{A}$, solidified King's medium B (KBA) and $\mathbf{B}$ to $\mathbf{D}$, at various times after inoculation on bean leaf surfaces. E, After 7 days, cells of Pseudomonas syringae B728a (pKT-trp) were recovered from leaves and grown on KBA for $48 \mathrm{~h}$. A and E, Cells grown in vitro were normally distributed with average cell lengths of $2.59 \pm 0.03 \mu \mathrm{m}(0.048, P>0.20)$ and $2.36 \pm 0.04 \mu \mathrm{m}(0.054, P>0.20)$, respectively. $\mathbf{B}, \mathbf{C}$, and $\mathbf{D}$, Cells recovered from bean plants 2,4 , and 7 days after inoculation exhibited a right-hand skewed distribution, which was described by a log-normal distribution with a mean size of $1.64 \pm 0.02 \mu \mathrm{m}$ $(0.026, P>0.20), 1.61 \pm 0.05 \mu \mathrm{m}(0.083, P<0.15)$, and $1.25 \pm 0 . \mu \mathrm{m}(0.066$, $P<0.15)$, respectively. Distributions denoted by the same italicized letters in parentheses do not differ $(P=0.05)$ according to Duncan's multiple range test of log-transformed data. The skewness of the distribution increased with time after incubation on leaves and was A, $0.42 \pm 0.14, \mathbf{B}, 0.54 \pm 0.09, \mathbf{C}$, $0.81 \pm 0.22, \mathbf{D}, 1.06 \pm 0.13$, and $\mathbf{E}, 0.28 \pm 0.17 \mu \mathrm{m}$. 
high nutrient conditions, whereas the majority of the cells encountered a low nutrient environment, resulting in cell size reduction.

\section{DISCUSSION}

This study reveals that the average cell size of $P$. syringae strain B728a grown on leaves, as determined by epifluorescence microscopy, was significantly smaller than cells grown in the presence of high nutrients in culture. After inoculation onto plants, the average cell size decreased rapidly, reaching a mean length and volume that was 2.0-fold and 3.6-fold smaller, respectively, than cells grown on $\mathrm{KBB}$.

The size of cells of $P$. syringae on colonized greenhouse plants mimicked the size of epiphytic bacterial cells on field-grown plants. We found that the length of bacterial cells naturally occurring on bean plants grown in the field, in which fluorescent $\mathrm{Pseu}$ domonas spp. predominated, had an average cell length of $1.2 \pm$ $0.02 \mu \mathrm{m}$ (data not shown), approximately the size of cells on greenhouse plants after 2 weeks (Fig. 2D). The cell size of strain B728a grown in culture and on leaf surfaces, as reported in this study, is comparable to cell sizes observed for other plant-pathogenic bacteria $(8,39)$. Bjorklof et al. (8) recently reported a similar twofold reduction in length 4 days after inoculation of cells of $P$. syringae strain Cit7 on bean leaves. The cell-cycle dependence of cell size of $P$. syringae pv. tabaci reported by Sigee and El-Masry (39) is most likely due to the depletion of nutrients in or on the plant rather than a cell-cycle effect per se as suggested, given that others studies have shown that bacterial growth on plants is limited by carbon availability (52). While our results are consistent with that of Bjorklof et al. (8), their study was not sufficiently detailed to infer rates of change of cell size or variations in cell size that are likely associated with a variable plant environment. In addition, our experiments were designed to allow for bacterial growth on leaves. Population sizes increased by 100 -fold after $24 \mathrm{~h}$ of incubation on plants, and therefore, less than $1 \%$ of the cells recovered during the course of the experiments were present in the inoculum.

We observed a rapid reduction in cell size following inoculation of leaf surfaces, even though the cells were still growing and the population size was increasing. These results demonstrate that some cell size reduction occurred even before stabilization of bacterial populations on leaves, while cells were multiplying, and reflect the relatively oligotrophic nature of the leaf surface environment. That is, even though the concentration of nutrients on most parts of the leaf was sufficient to allow cell multiplication, it was probably far less than in culture media, thus triggering cell size reduction. However, when overall growth had ceased and epiphytic populations had stabilized, cell size reduction continued to occur, at a slower rate, to reach an apparent minimum size. This suggests that the concentration of nutrients at such times is very low. The rapid decrease in bacterial cell size that occurs immediately after inoculation (Fig. 5) seems to reflect nutrient availability. The smaller decrease observed a few days later could reflect other conditions experienced by bacteria on leaves, such has low water availability or osmotic stress. When compared with nutrients, such conditions seem, however, to have a lesser effect on cell size. We hypothesize that the average minimum cell size of a given bacterial strain, under the same experimental conditions, reflects primarily the relative abundance of nutrients present on a leaf and thus can be used as an indicator of nutrient availability on the leaf surfaces of different plant species.

As with other bacteria, the size of $P$. syringae cells in culture appears to be proportional to the amount of nutrients to which it is exposed. The larger size of cells grown on KBB compared with KBA can be explained by the fact that KBB cultures were shaken, which would constantly homogenize the environment around the cells, exposing them to all available nutrients in the medium, as opposed to an agar surface in which local depletion of nutrients within a colony would be expected. Likewise, cells starved by the absence of carbon compounds were only half the size of cells grown in $\mathrm{KBB}$; this size reduction is similar to that observed for E. coli $(26)$ and other bacteria $(9,46)$ under these conditions. Interestingly, upon reculturing of cells recovered from leaves, we observed a reversion in cell size. This phenotypic plasticity indicates that $P$. syringae changes its cell size depending on the nature of its nutritional environment and that such changes reflect changes in the environment to which the cells have been exposed and not selection of genetic variants of a small size under these conditions. By adjusting their size, bacteria could optimize their surface-tovolume ratio and consequently their nutrient uptake capacity.

Several studies have reported that bacteria exposed to nutrient deprivation both become smaller and develop increased resistance to abiotic stress $(10,17,42,46,47)$. Interestingly, Givskov et al. (13) reported that the physiological state of cells of $P$. putida following carbon starvation is apparently protective against a wide array of adverse conditions and can result in cross-protection against various stress conditions. There is evidence that cells of $P$. syringae on leaf surfaces are more stress tolerant than those grown in culture. Wilson and Lindow (50) found that cells of $P$. syringae recovered from bean leaf surfaces and then reapplied to leaves subsequently exposed to stressful field conditions survived much better than cells grown in either solid or liquid culture media (50). While these authors did not assess the size of plant-derived cells, they most likely were smaller than the cultured cells since the same plant species and similar strains of $P$. syringae as used here were studied (50). Survival of bacteria on the leaf surface is thought to be achieved through either stress avoidance or stress tolerance $(6,7)$. Bacteria are thought to escape stresses by colonizing protected sites on the leaf surfaces or by forming aggregates surrounded by an exopolymeric matrix (32). However, we and others $(28,40)$ have observed a large number of living cells located in nonprotected sites such as the top of epidermal plant cells. Given that the majority of cells immigrating to a leaf apparently experience low nutrient conditions, because their cell size rapidly decreases upon arrival on a plant, these cells may enter a more stress-tolerant state, enhancing their ability to survive during initial colonization stages. Thus, while epiphytic bacteria that occur in aggregates or protected sites may escape stress, other more exposed cells may adapt to the harsh conditions of epiphytic life by modulating their size and therefore becoming more resistant to different environmental stresses. These observations suggest that epiphytic bacterial cells found in nutrient-limited sites might be less susceptible to bactericides applied for disease control. Indeed, Andersen et al. (1) reported that populations of $P$. syringae on inoculated plants become less susceptible to applied $\mathrm{Cu}(\mathrm{OH})_{2}$ with time.

Because cell size reduction apparently is a correlated response to nutrient limitation $(10,11,30,44,45)$, measurements of cell size of bacteria in natural habitats provide an indirect estimation of the heterogeneity of nutrient availability. Cells grown in culture exhibited a normal size distribution, whereas cells recovered from bean plants at various times after inoculation exhibited a righthand skewed distribution. The skewness of the distribution increased through time, reflecting an increasing proportion of small cells, even though some cells remained large (Fig. 6). The largest cells recovered from plants were representative of the typical cultured cells. We interpreted this to mean that most cells inoculated onto leaves experienced relatively low nutrient concentrations, while a few enjoyed substantial resources, at least for a few days after inoculation. Our conjecture that only the few large cells observed on leaves experienced high nutrients is also supported by recent estimates of the sugar abundance encountered by epiphytic bacteria on plants (24). These workers, using a strain of Erwinia herbicola that produced GFP fluorescence in a fructose-dependent fashion, have shown that most of such cells depleted fructose in their vicinity within a few hours after inoculation onto plants and 
that less than $1 \%$ of the cells were metabolically active and still exposed to fructose after 1 day (24). While they did not report the size of the cells, it is tempting to speculate that such cells would have retained a larger cell size while most others that became limited for carbon compounds on the leaf would have begun to shrink as an adaptive response, as shown in other studies $(2-4,12,17$, $20,23,35,42,46)$. Together, these results support recent studies that indicate that the nutritional environment of the leaf is heterogeneous $(24,29)$; the majority of immigrant cells are exposed to oligotrophic conditions or do not have access to nutrients at all, while a small fraction of larger cells seem to be exposed to a more copiotrophic environment similar to the one encountered by cells grown in culture.

The small fraction of large cells observed were at the base of glandular trichomes and often formed small aggregates, which corroborates previous reports of aggregates observed on leaf surfaces (32) (J.-M. Monier and S. E. Lindow, unpublished data) and suggests that extensive microbial activity is possible only at such sites on nonwounded leaves. Small cells were mostly solitary and further away from these sites. We hypothesize that the presence of large cells forming small aggregates is the result of the presence of a localized, nutrient-rich environment that allows multiplication and growth of the cells. We propose that small, solitary cells derive from larger cells that have become smaller due to starvation or result from cell divisions under these conditions, because two to four small cells often were observed together on a leaf. These observations seem to contradict the recent report that, after 4 days of incubation on bean leaf surfaces, metabolically active cells of $P$. syringae recovered from bean leaves often were the small cells (8). However, in our study, estimates of individual cell size directly on leaves could not have been done for cells present in larger aggregates $(n>100$ cells) because they were not visibly separable as single cells. We do not preclude the possibility that cells in large aggregates might eventually become smaller as a consequence of active growth that leads to subsequent nutrient depletion.

Observation of cell size modulation of bacteria on leaves is a valuable tool to study epiphytic bacteria at the small scales over which they are influenced by the plant and brings new insight to the understanding of this important group of bacteria. While nutrient availability on leaves affects the number of epiphytic bacteria present on different plant species (29), it may also affect the size of bacterial epiphytes. Thus, the study of bacterial cell size should provide information on the nature of a specific leaf habitat.

\section{ACKNOWLEDGMENTS}

This study was supported by grant 96-35303-3377 from the U.S. Department of Agriculture Competitive Grants Program of the National Research Initiative and by grant DR-F603-86ER13518 from the Department of Energy. We thank S. Ruzin and D. Schichnes from the Biological Imaging Facility at the University of California, Berkeley, for their assistance with microscopy, and J. Leveau and B. Quiñones for their helpful suggestions on the manuscript.

\section{LITERATURE CITED}

1. Andersen, G. L., Menkissoglou, O., and Lindow, S. E. 1991. Occurrence and properties of copper-tolerant strains of Pseudomonas syringae isolated from fruit trees in California. Phytopathology 81:648-656.

2. Bae, H. C., and Casida, L. E. 1973. Responses of indigenous microorganisms to soil incubation as viewed by transmission electron microscopy of cell thin sections. J. Bacteriol. 113:1462-1473.

3. Baker, L. R., Singleton, F. L., and Hood, M. A. 1983. Effects of nutrient deprivation on Vibrio cholerae. Appl. Environ. Microbiol. 46:930940.

4. Bakken, L. R., and Olsen, R. A. 1987. The relationship between cell size and viability of soil bacteria. Microbiol. Ecol. 13:103-114.

5. Baldwin, W. W., Sheu, M. J. T., Bankston, P. W., and Woldringh, C. L. 1988. Changes in buoyant density and cell size of Escherichia coli in response to osmotic shocks. J. Bacteriol. 170:452-455.
6. Beattie, G. A., and Lindow, S. E. 1995. The secret life of foliar bacterial pathogens on leaves. Annu. Rev. Phytopathol. 33:145-172.

7. Beattie, G. A., and Lindow, S. E. 1999. Bacterial colonization of leaves: A spectrum of strategies. Phytopathology 89:353-359.

8. Bjorklof, K., Nurmiaho-Lassila, E. L., Klinger, N., Haahtela, K., and Romantschuk, M. 2000. Colonization strategies and conjugal gene transfer of inoculated Pseudomonas syringae on the leaf surface. J. Appl. Microbiol. 89:423-432.

9. Caro, A., Got, P., and Baleux, B. 1999. Physiological changes of Salmonella typhimurium cells under osmotic and starvation conditions by image analysis. FEMS Microbiol. Lett. 179:265-273.

10. Clements, M. O., and Foster, S. J. 1999. Stress resistance in Staphylococcus aureus. Trends Microbiol. 7:458-462.

11. Fuhrman, J. A., Sleeter, T. D., Carlson, C. A., and Proctor, L. M. 1989. Dominance of bacterial biomass in the Sargasso Sea [Atlantic Ocean] and its ecological implications. Mar. Ecol. Prog. Ser. 57:207-218.

12. Givskov, M., Eberl, L., and Molin, S. 1994. Responses to nutrient starvation in Pseudomonas putida KT2442: Two-dimensional electrophoretic analysis of starvation- and stress-induced proteins. J. Bacteriol. 176:4816-4824.

13. Givskov, M., Eberl, L., Moller, S., Poulsen, L. K., and Molin, S. 1994. Responses to nutrient starvation in Pseudomonas putida KT2442: Analysis of general cross-protection, cell shape, and macromolecular content. J. Bacteriol. 176:7-14.

14. Godfrey, B. E. S. 1976. Leachates from aerial parts of plants and their relation to plant surface microbial populations. Pages 433-439 in: Microbiology of Aerial Plant Surfaces. C. H. Dickinson and T. H. Preece, eds. Academic Press, London.

15. Groat, R. G., Schultz, J. E., Zychlinsky, E., Bockman, A., and Matin, A. 1986. Starvation proteins in Escherichia coli: Kinetics of synthesis and role in starvation survival. J. Bacteriol. 168:486-493.

16. Hallmann, J., Quadt-Hallmann, A., Miller, W. G., Sikora, R. A., and Lindow, S. E. 2001. Endophytic colonization of plants by the biocontrol agent Rhizobium etli G12 in relation to Meloidogyne incognita infection. Phytopathology 91:415-422.

17. Hase, C., Mascher, F., Moenne-Loccoz, Y., and Defago, G. 1999. Nutrient deprivation and the subsequent survival of biocontrol Pseudomonas fluorescens CHA0 in soil. Soil Biol. Biochem. 31:1181-1188.

18. Hirano, S. S., Rouse, D. I., and Upper, C. D. 1987. Bacterial ice nucleation as a predictor of bacterial brown spot disease on snap beans. Phytopathology 77:1078-1084.

19. Hirano, S. S., and Upper, C. D. 2000. Bacteria in the leaf ecosystem with emphasis on Pseudomonas syringae: A pathogen, ice nucleus, and epiphyte. Microbiol. Mol. Biol. Rev. 64:624-653.

20. Humphreys, B., Kjelleberg, S., and Marshall, K. C. 1983. Responses of marine bacteria under starvation conditions at a solid-water interface. Appl. Environ. Microbiol. 45:43-47.

21. Kjelleberg, S., Albertson, N., Flardh, K., Jouper-Jann, A., Marouga, R., Ostling, J., Svenblad, B., and Weichart, D. 1993. How do nondifferentiating bacteria adapt to starvation? Antonie Leeuwenhoek 63:333-341.

22. Koch, A. L. 1984. Shrinkage of growing Escherichia coli cells by osmotic challenge. J. Bacteriol. 159:919-924.

23. Lange, R., and Hengge-Aronis, R. 1991. Growth phase-regulated expression of bolA and morphology of stationary-phase Escherichia coli cells are controlled by the novel sigma factor $\sigma^{\mathrm{s}}$. J. Bacteriol. 173:44744481.

24. Leveau, J. H. J., and Lindow, S. E. 2001. Appetite of an epiphyte: Quantitative monitoring of bacterial sugar consumption in the phyllosphere. Proc. Natl. Acad. Sci. USA 98:3446-3453.

25. Lindeman, J., Arny, D. C., and Upper, C. D. 1984. Use of an apparent infection threshold population of Pseudomonas syringae to predict incidence and severity of brown spot on bean. Phytopathology 74:13341339.

26. Lisle, J. T., Broadaway, S. C., Prescott, A. M., Pyle, B. H., Fricker, C., and McFeters, G. A. 1998. Effects of starvation on physiological activity and chlorine disinfection resistance in Escherichia coli O157:H7. Appl. Environ. Microbiol. 64:4658-4662.

27. Loper, J. E., and Lindow, S. E. 1987. Lack of evidence for in situ fluorescent pigment production by Pseudomonas syringae pv. syringae on bean leaf surfaces. Phytopathology 77:1449-1454.

28. Mariano, R. L. R., and McCarter, S. M. 1993. Epiphytic survival of Pseudomonas viridiflava on tomato and selected weed species. Microbiol. Ecol. 26:47-58.

29. Mercier, J., and Lindow, S. E. 2000. Role of leaf surface sugars in colonization of plants by bacterial epiphytes. Appl. Environ. Microbiol. 66:369-374.

30. Moriarty, D. J. W., and Bell, R. T. 1993. Bacterial growth and starvation in aquatic environments. Pages 25-53 in: Starvation in Bacteria. S. Kjelleberg, ed. Plenum Press, New York. 
31. Morita, R. Y. (ed.) 1997. Bacteria in Oligotrophic Environments: Starvation-Survival Lifestyle. Chapman \& Hall, Inc., New York.

32. Morris, C. E., Monier, J.-M., and Jacques, M.-A. 1997. Methods for observing microbial biofilms directly on leaf surfaces and recovering them for isolation of culturable microorganisms. Appl. Environ. Microbiol. 63:1570-1576.

33. Morris, C. E., and Rouse, D. I. 1985. Role of nutrients in regulating epiphytic bacterial populations. Pages 63-82 in: Biological Control on the Phylloplane. C. E. Windels and S. E. Lindow, eds. The American Phytopathological Society, St. Paul, MN.

34. Novitsky, J. A., and Morita, R. Y. 1976. Morphological characterization of small cells resulting from nutrient starvation of a psychrophilic marine vibrio. Appl. Environ. Microbiol. 32:617-622.

35. Postma, J., Van Elsas, J. D., Govaert, J. M., and Van Veen, J. A. 1988. The dynamics of Rhizobium leguminosarum biovar trifolii introduced into soil as determined by immunofluorescence and selective plating techniques. FEMS Microbiol. Ecol. 53:251-260.

36. Roszak, D. B., and Colwell, R. R. 1987. Survival strategies of bacteria in the natural environment. Microbiol. Rev. 51:365-379.

37. Rouse, D. I., Nordheim, E. V., Hirano, S. S., and Upper, C. D. 1985. A model relating the probability of foliar disease incidence to the population frequencies of bacterial plant pathogens. Phytopathology 75:505-509.

38. Sambrook, J., Fritsch, E. F., and Maniatis, T. 1989. Molecular Cloning: A Laboratory Manual. Cold Spring Harbor Laboratory, Cold Spring Harbor, NY.

39. Sigee, D. C., and El-Masry, M. H. 1989. Changes in cell size and flagellation in the phytopathogen Pseudomonas syringae pv. tabaci cultured in vitro and in planta: A comparative electron microscope study. J. Phytopathol. (Berlin) 125:217-230.

40. Surico, G. 1993. Scanning electron microscopy of olive and oleander leaves colonized by Pseudomonas syringae ssp. savastanoi. J. Phytopathol. (Berlin) 138:31-40.

41. Tabor, P. S., Ohwada, K., and Colwell, R. R. 1981. Filterable marine bacteria found in the deep sea: Distribution, taxonomy and response to starvation. Microbiol. Ecol. 7:67-81.

42. Troxler, J., Zala, M., Natsch, A., Moenne-Loccoz, Y., and Defago, G. 1997. Autecology of the biocontrol strain Pseudomonas fluorescens
CHA0 in the rhizosphere and inside roots at later stages of plant development. FEMS Microbiol. Ecol. 23:119-130.

43. Tukey, H. B. J. 1970. The leaching substances from plants. Annu. Rev. Plant Physiol. 21:305-324.

44. Van Duyl, F. C., Bak, R. P. M., Kop, A. J., and Nieuwland, G. 1990. Bacteria, autotrophic and heterotrophic nanoflagellates, and their relations in mixed, frontal and stratified waters of the North Sea. Neth. J. Sea Res. 26:97-110.

45. Van Duyl, F. C., and Kop, A. J. 1988. Temporal and lateral fluctuations in production and biomass of bacterioplankton in the western Dutch Wadden Sea. Neth. J. Sea Res. 22:51-68.

46. Van Overbeek, L. S., Eberl, L., Givskov, M., Molin, S., and Van Elsas, J. D. 1995. Survival of, and induced stress resistance in, carbon-starved Pseudomonas fluorescens cells residing in soil. Appl. Environ. Microbiol. 61:4202-4208.

47. Watson, S. P., Clements, M. O., and Foster, S. J. 1998. Characterization of the starvation-survival response of Staphylococcus aureus. J. Bacteriol. 180:1750-1758.

48. Wiebe, W. J., Sheldon, W. M., Jr., and Pomeroy, L. R. 1992. Bacterial growth in the cold: Evidence for an enhanced substrate requirement. Appl. Environ. Microbiol. 58:359-364.

49. Wilson, M., Hirano, S. S., and Lindow, S. E. 1999. Location and survival of leaf-associated bacteria in relation to pathogenicity and potential for growth within the leaf. Appl. Environ. Microbiol. 65:1435-1443.

50. Wilson, M., and Lindow, S. E. 1993. Effect of phenotypic plasticity on epiphytic survival and colonization by Pseudomonas syringae. Appl. Environ. Microbiol. 59:410-416.

51. Wilson, M., and Lindow, S. E. 1994. Ecological similarity and coexistence of epiphytic ice-nucleating (Ice+) Pseudomonas syringae strains and a non-ice-nucleating (Ice-) biological control agent. Appl. Environ. Microbiol. 60:3128-3137.

52. Wilson, M., and Lindow, S. E. 1994. Coexistence among epiphytic bacterial populations mediated through nutritional resource partitioning. Appl. Environ. Microbiol. 60:4468-4477.

53. Wilson, M., Savka, M. A., Hwang, I., Farrand, S. K., and Lindow, S. E. 1995. Altered Epiphytic colonization of mannitol opine-producing transgenic tobacco plants by a mannitol opine-catabolizing strain of Pseudomonas syringae. Appl. Environ. Microbiol. 61:2151-2158. 